earth's magnetism, according to the method described by $\mathrm{Mr}$. Andrew Gray (NATURE, vol. xxvii. p. 32), might not be without interest to some readers, as showing the amount of accuracy which can be obtained. The experiments were made by one of my students at this College about four months ago.

The form of reflecting galvanometer which lends itself best to these experiments is one devised by Prof. Stuart, in which the needle is centrally situated between two rectangular pieces of word carrying the coils. To the sides of these, two boards can be easily attached by brackets, so as to be in the same plane as the needle, and quite horizontal, and in this position do not interfere with the light falling upon or reflected from the mirror. The reflecting magnet is then north or south of the needle, and perpendicular to it.

The magnets were made from thin knitting needles (about No. 19, B.W.G.), cut to the proper length, and made glass hard. They were made in two lengths, 8.5 and $12.5 \mathrm{~cm}$., but the longer ones were slightly warped in hardening, and did not give concordant results. The scale was at a uniform distance of $62.5 \mathrm{~cm}$. from the mirror, and in reading the deflections four observations were made and again repeated after noting the times of oscillation, as described by Mr. Gray. Each of the deflections given below is therefore the mean of eight observations.

The following are the details of the experiments :-

Denomination of magnet. A. B. C.

Length ... $\quad \ldots \quad \ldots 8.5 \mathrm{~cm} . \quad \ldots 8.5 \mathrm{~cm} . \quad \ldots 8.5 \mathrm{~cm}$.

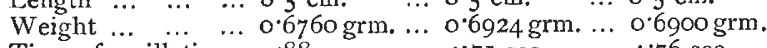

Time of oscillation.. 4.88 sec. $\quad \ldots 4.7$ r sec. $\quad \ldots 4.76 \mathrm{sec}$

Deflection at $15 \mathrm{~cm} .7 .1 \mathrm{~cm}, \quad \ldots 7.7 \mathrm{~cm} . \quad \ldots 7^{\circ} 6 \mathrm{~cm}$ " I3 " $\quad 10 \cdot 6 \mathrm{~cm}$. $\quad \ldots 1 \mathrm{II} 5 \mathrm{~cm}$. $\quad \ldots$ II $2 \mathrm{~cm}$.

From these results we obtain, by aid of the formula :-

$$
H=\sqrt{\frac{4}{3} \frac{\pi^{2} l^{2} w}{\left(r^{2}+l^{2}\right)^{2} T^{2} \tan \theta}},
$$

the following values for $H$ :-

$$
\begin{array}{cl}
0.17705 \\
0.17635 \\
0.17828 \\
0.17754 \\
0.17725 \\
0.17770 \\
\text { Mean }= & 0.17736 \pm 0.00048,
\end{array}
$$

showing an amount of accuracy which may, I think, be compared with that obtained with much more expensive and delicate apparatus.

T. S. HUMPIDGE

University College of Wales, Aberystwytb, June 27

\section{The Lachine Aërolite}

THE most remarkable fall of an aërolite that has yet been recorded took place at Lachine, about eight miles from Montreal, on Saturday, July 7,1883 . I give the following account from the Montreal Daily Star of July I I :-

"The fall of the aërolite transpired during a rain shower on the forennon of Saturday, and there were no premonitory indications to show that the air was more than usually charged with electricity. The person who witnessed the fall of the aërolite more clearly than any one else was Mrs. Popbam, wife of Mr. John Popham, insurance agent. Mrs. Popham was seated in her house up stairs sewing, when all of a sudden the apartment became illuminated with a plinding flash of light. 'I he lady instantly glanced out of the window, when to her astonishment she beheld a huge mass of fire descending towards the earth in a diagonal direction. This brilliant body had a solid nucleus that appeared to the eye abont four feet square, and a strange, indescribable noise was caused by its flight through the air. Simultaneously, as it seemed to Mrs. Popham, she received a paralysing shock that affected her from head to foot, as if the entire contents of a highly-charged battery had been discharged into her body at once. The astonishing brilliancy of the meteor caused a temporary loss of sight, and it was fully half an hour before the lady could distinguish surrounding objects. When Mrs. Popham first beheld the falling mass she fancied that it was about to strike the house, and is still of the opinion that it must have passed alarmingly close. The lady took several hours to recover from the shock, and when Mr. Popham returned home several hours after he found her partially prostrated from its effects.

"Mr. McNaughton, a brother of Mrs. Popham, was sitting down stairs reading when the flash came. He jumped up, and, looking out of the window under the trees towards the river, he plainly saw the fiery ball strike the water at a little oistance from the shore, causing a mountainous upheaval and sending splashes in every direction.

"Mr. Horace Baby also saw the glare caused by the fiight of the meteor, although he did not actually see the body itself. He said that he felt a tremendous shock, and that he could feel the electricity oozing out of his finger-ends for some time after.

"Mr. C. P. Davidson, Q.C., was sitting down to lunch at the time, and describes the crash as being tremendous. The Rawlings family also felt the shock severely, as indeed did balf the village. Mr. Popham's cottage stands about seventy feet from the water's edge at Stony Point, and it is thought that the aërolite fell into the stream about twenty or thirty yards from the shore, in about twenty feet of water. Owing to the high winds since the occurrence the water has reen so muddy that it has been im possible to locate the whereabouts of the meteor. An attempt, however, will shortly be made to bring it to the surface."

I will send further details when they come to hand.

E. W. Claypole

New Bloomfield, Perry Co., Pennsylvania, July I5

\section{Cold and Sunspots}

Your correspondent, Mr. C. J. B. Williams, is wrong in the statement he makes in NATURE, vol. xxviii. p. IO3, concerning the cold in California in the month of March. The month was the warmest March we have had for some years, the mean temperature being $3^{\circ} \cdot 5$ above the average, and $2^{\circ} \cdot 8$ above the average for the whole of the Pacific coast. February, on the contrary, was a very cold month, the mean temperature being $3^{\circ} 6$ below the average. I believe it will be found that the mean temperature of a hemisphere is not affected by sunspots. That the seasons, however, are influenced by the state of the sun's surface I have no doubt, but this only in a secondary manner. In a paper read before the California Academy of Sciences in 1870 (see Proceedings, vol. iv. p. I 28 ), I pointed out that our extreme seasonal climates were caused by the prevalence of broad belts of north and south winds which would extend continuously from east to west for 1500 or 2000 miles, and would blow over the same surface for months together, causing extreme seasons with temperalures above the average where the south current prevailed, and cold winters where there was a northerly current.

As a general rule when there is a cold winter on the Pacific coast the winter in the Eastern States is mild. The following figures taken from the U.S. Meteorological Reports will illustrate what I mean :--

$$
\text { Mean Tentzerature for February } 1883
$$

Below the Average North Pacific States ..

Middle Pacific region

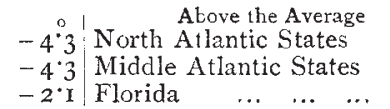

$+2: 2$ South Pacific region $-2 \cdot 1$ Florida

Thus while on the whole of the Pacific co of the while $x$ as from $4 \cdot 3$ to $2^{\circ}$. I below the average, on the Atlantic coast the temperature was from $6^{\circ} \cdot 3$ to $2^{\circ} \cdot 2$ above the average.

Towards the end of February the north current that had been prevailing over the western regions of the continent during the whole of the winter shifted to the east, and this change of longitude was accompanied by some of the worst cyclones that have visited the central and middle States for years.

During the month of March, whilst we were under the régime of a south current, the temperature in the Eastern States was low, the temperature in Massachusetts for March being $7^{\circ} 3$ below the average.

My own belief is that the connection between the character of our seasons and sunspots will have to be worked out through the influence of the sun on the regional distribution of air currents.

San Francisco, Cal., July 3

JAMES BLAKE

Intelligence in Animals-Can a Viper Commit Suicide?

HAVING cccasionally caught a viper, and kept it for a time in a glass case, one of the platelayers called me last Thursday and said "there was a fine 'Long Cripple' (a local name for a 